\title{
Efficacy and tolerability of preservative-free tafluprost $0.0015 \%$ in Korean patients with glaucoma
}

This article was published in the following Dove Press journal:

Clinical Ophthalmology

17 December 2013

Number of times this article has been viewed

\section{Young Hoon Hwang}

Department of Ophthalmology, Konyang University, Kim's Eye Hospital, Myung-Gok Eye Research Institute, Seoul, Korea
Correspondence: Young Hoon Hwang Department of Ophthalmology, Kim's Eye Hospital, \#I56 Youngdeungpo-dong 4ga, Youngdeungpo-gu, Seoul I50-034, Korea Tel +82 226397777

Fax +82 226333976

Email brainh@hanmail.net

\section{Dear editor}

I read with interest the article entitled "Preservative-free tafluprost in the treatment of naive patients with glaucoma and ocular hypertension" by Lanzl et al. ${ }^{1}$ I have also experienced similar treatment outcomes in Korean patients. In Korea, preservative-free tafluprost (Taflotan-S; Santen Pharmaceutical Co, Ltd, Osaka, Japan) was introduced to the ophthalmic market in October 2012. Thus far, no data have been published on the efficacy and tolerability of preservative-free tafluprost in Korean patients. Thus, I investigated the intraocular pressure (IOP)-lowering efficacy and safety of preservative-free tafluprost in treatment-naïve Korean patients with glaucoma.

This study included 58 Korean primary open-angle glaucoma patients who had not undergone previous glaucoma treatment. Preservative-free tafluprost was prescribed to the primary open-angle glaucoma patients and the patients were scheduled to visit the clinic after 1, 3, and 6 months of treatment. The mean (standard deviation) IOP of 58 eyes in 58 patients at the baseline visit was 20.0 (4.6) (range, 12-32) mmHg. After treatment with preservative-free tafluprost, the mean IOP decreased to $15.5(2.5) \mathrm{mmHg}$ (4.6 $\mathrm{mmHg}$ [23.0\%] reduction from baseline) at 1 month after treatment, to 14.9 (2.8) $\mathrm{mmHg}(5.1 \mathrm{mmHg}[25.5 \%]$ reduction from baseline) at 3 months after treatment, and to 15.1 (2.6) $\mathrm{mmHg}(4.9 \mathrm{mmHg}$ [24.5\%] reduction from baseline) at 6 months after treatment, respectively. No significant difference was found in IOP among 1, 3, and 6 months of treatment $(P>0.05)$. Irritation/stinging/burning sensation, itching, tearing, and dryness were reported by 5 (8.6\%), 2 (3.4\%), 2 (3.4\%), and $9(15.5 \%)$ patients, respectively, during the treatment period. None, mild, moderate, and severe conjunctival hyperemia was observed in 43 (74.1\%), 13 (22.4\%), 2 (3.4\%), and $0(0 \%)$ eyes after treatment, respectively. No eye showed corneal staining during the treatment period.

According to my clinical experience, preservative-free tafluprost was both well tolerated and effective for IOP reduction in treatment-naïve Korean glaucoma patients. Therefore, I think that preservative-free tafluprost may be a good treatment regimen for glaucoma in Korean patients.

\section{Disclosure}

The author reports no conflicts of interest in this correspondence.

\section{References}

1. Lanzl I, Hamacher T, Rosbach K, et al. Preservative-free tafluprost in the treatment of naive patients with glaucoma and ocular hypertension. Clin Ophthalmol. 2013;7:901-910. 


\section{Publish your work in this journal}

Clinical Ophthalmology is an international, peer-reviewed journal covering all subspecialties within ophthalmology. Key topics include: Optometry; Visual science; Pharmacology and drug therapy in eye diseases; Basic Sciences; Primary and Secondary eye care; Patient Safety and Quality of Care Improvements. This journal is indexed on
PubMed Central and CAS, and is the official journal of The Society of Clinical Ophthalmology (SCO). The manuscript management system is completely online and includes a very quick and fair peer-review system, which is all easy to use. Visit http://www.dovepress.com/ testimonials.php to read real quotes from published authors. 